\title{
Source of carbohydrate and metabolizable lysine and methionine in the diet of recently weaned dairy calves on digestion and growth
}

\author{
T. M. Hill, ${ }^{1}$ J. D. Quigley, H. G. Bateman II, ${ }^{2}$ J. M. Aldrich, and R. L. Schlotterbeck \\ Nurture Research Center, Provimi, Brookville, $\mathrm{OH} 45309$
}

\section{ABSTRACT}

Two 56-d trials with weaned Holstein dairy calves (initially $72 \pm 1.8 \mathrm{~kg}$ of body weight, 58 to $60 \mathrm{~d}$ of age) fed $95 \%$ concentrate and $5 \%$ chopped grass hay diets were conducted. Each trial used 96 calves (4 calves/ pen). During 15 of the last $21 \mathrm{~d}$ of the first trial and 10 of $14 \mathrm{~d}$ of the second and third week of the second trial, fecal samples were taken to estimate digestibility using acid-insoluble ash as an internal marker. Digestibility estimates along with 56-d average daily gain (ADG), hip width change, body condition score, and fecal score were analyzed with pen as the experimental unit. In trial 1, a textured diet (19\% crude protein) with high starch [52\% starch, 13\% neutral detergent fiber (NDF)] based on whole corn and oats or a pelleted low-starch (20\% starch, 35\% NDF), high-digestible fiber diet were used. Within starch level, diets were formulated from supplemental soybean meal or soybean meal with blood meal and Alimet (Novus International Inc., St. Charles, $\mathrm{MO}$ ) to provide 2 metabolizable protein levels (1 and $1.07 \%$ metabolizable lysine plus methionine). The 4 treatments were analyzed as a completely randomized design with a 2 by 2 factorial arrangement (6 pens/ diet). In trial 2 , all pelleted diets ( $19 \%$ crude protein) were fed. Diets were based on soybean hulls, wheat middlings, or corn, which contained increasing concentrations of starch $(13,27$, and $42 \%$ starch and 42 , 23 , and $16 \%$ NDF, respectively; 8 pens/diet). Contrast statements were constructed to separate differences in the means (soybean hulls plus wheat middlings vs. corn; soybean hulls vs. wheat middlings). In trial 1, intake of organic matter (OM) did not differ. Digestibility of OM was greater in calves fed high- versus low starch-diets. Digestibility of NDF and starch were less in calves fed the high- versus low-starch diets. Calf ADG and hip width change were greater for high- versus low-starch diets. Source of protein did not influence digestibility or ADG. In trial 2, intake of OM was not different.

Received October 28, 2015.

Accepted December 23, 2015

${ }^{1}$ Corresponding author: mhill@provimi-na.com

${ }^{2}$ Deceased.
Digestibility of OM was greater in calves fed corn versus other diets. Digestibility of NDF was greater for calves fed soybean hulls versus wheat middlings. Starch digestibility was not different among treatments. Calf ADG and hip width change were greater in calves fed corn versus other diets. High-starch diets were more digestible and supported more growth in 2- to 4-mo-old dairy calves than replacing starch with digestible fiber. Manipulating metabolizable protein compared with a control diet that was predominately corn and soybean meal did not alter growth or digestibility.

Key words: starch, fiber, protein, calf

\section{INTRODUCTION}

In the US dairy calf industry, a diversity of starter and grower feeds are fed to dairy calves less than 4 mo of age. These feeds vary greatly in their $\mathrm{CP}$ and digestible energy (DE) or ME concentration and ingredient composition. The NRC (2001) requirements mention the need for digestible fiber components, but limited data exist to substantiate this statement. The recently weaned calf or calf transitioning from milk or milk replacer to dry feed is an area of research in which limited knowledge has been gained since the NRC (2001) requirements were published (Hill et al., 2013).

Manipulation of nutrients offered to weaned calves within the dairy calf submodel of the NRC (2001) requirements suggest that energy, not $\mathrm{CP}$, limits $\mathrm{ADG}$ in most circumstances. Digestible fiber sources such as soybean hulls, wheat middlings, and distillers dried grains with solubles have a lower $\mathrm{DE}$ (or ME) value than corn or other grains which are high in starch (NRC, 2001). The rumen of a weaned calf is small, leading to short retention times for digestion. VazquezAnon et al. (1993) reported mean retention of particles in the rumen of calves approximately double between 7 and 13 wk of age, relating to the increasing rumen size. Because digestible fiber is typically degraded in the rumen at a lower rate than starch, digestible fiber may increase in value to the calf diet as the calf ages; however, recent data suggests there are no benefits to reduced ADG from replacing corn with digestible fiber sources (Hill et al., 2008a, 2012; Suarez-Mena et al., 
2011; Terré et al., 2013), substantiating lower DE or ME concentrations than corn in NRC (2001). Despite these data, a pelleted high-fiber diet is frequently fed to calves less than 5 mo of age in the US dairy industry.

Recent publications suggest a $\mathrm{CP}$ concentration of $20.5 \%$ of $\mathrm{DM}$ ( $63 \mathrm{~g}$ of $\mathrm{CP} / \mathrm{Mcal}$ of $\mathrm{ME}$ ) for calves less than 8 wk of age (Hill et al., 2007a, 2008b; Stamey et al., 2012) and less than 17 (to maximize ADG) to $18 \%$ of DM (to maximize feed efficiency; 52 to $56 \mathrm{~g}$ of $\mathrm{CP} /$ Mcal of ME) for calves 2 to 4 mo of age are adequate (Hill et al., 2008b); this supports the limited data from which NRC (2001) is based. Source of rumen-undegraded protein or high MP has not resulted in more calf growth than diets based on soybean meal and corn (Warner, 1984; Hill et al., 2007a, 2008b). The dairy calf submodel of the NRC (2001) requirements does not consider MP or AA. Additionally, many diets fed to calves in the US dairy market contain sources of undegraded protein and metabolizable Lys and Met beyond what is supplied by soybean meal, especially when high-fiber diets are fed.

The objectives of these trials were to investigate the effect of starch or digestible fiber concentration of a diet and its interaction with metabolizable Lys and Met content of a diet on calf growth and digestion of nutrients. The diets tested represent compositions and forms commonly fed in the United States. Use of digestibility measurements will assist in interpretation of growth data that might be skewed with gut fill. These data will help to fill a void of research before and after the NRC (2001) requirements were published.

\section{MATERIALS AND METHODS}

Calves were cared for by acceptable practices as described in the Guide for the Care and Use of Agricultural Animals in Research and Teaching (FASS, 2010). Two 56-d trials were conducted with weaned, male Holstein dairy calves (initially $72 \pm 1.8 \mathrm{~kg}$ of BW, 58 to $60 \mathrm{~d}$ of age, sourced from 1 farm) fed $95 \%$ concentrate and $5 \%$ chopped grass hay diets. The calves had been weaned for $2 \mathrm{wk}$ before the trials started. Each trial used 96 calves ( 4 calves/pen) with 2 starting times 5 wk apart as blocks (48 calves/block). During 15 of the last $21 \mathrm{~d}$ of trial 1 and 10 of $14 \mathrm{~d}$ of the second and third week of trial 2, fecal samples were collected to estimate the digestibility of the diets fed. Performance measurements were made over the 56-d trial. The calves were housed in group pens with $5.5 \mathrm{~m}^{2}$ of outside pen space and 1.35 $\mathrm{m}^{2}$ of inside pen space per calf. The inside pen space was bedded with straw and there was no added heat.

In trial 1, a textured diet (19\% CP on DM basis) with high starch (52\% starch, 13\% NDF) based on whole corn and oats or a pelleted low-starch $(20 \%$ starch, 35\% NDF), high-digestible fiber diet were used. Within starch level, diets were formulated from all supplemental soybean meal or soybean meal with blood meal and Alimet [Novus International Inc., St. Charles, MO; 84\% 2-hydroxyl 4-(methylthio) butanoic acid, $88 \%$ methionine activity] to provide $2 \mathrm{MP}$ levels (1 and 1.07\% metabolizable Lys plus Met). The trial was conducted from June to September. The average temperature during the trial was $26^{\circ} \mathrm{C}$ (ranged from 9 to $40^{\circ} \mathrm{C}$ ) and average humidity was $60 \%$ (ranged from 29 to $99 \%$ ). The 4 treatments were analyzed as a completely randomized block design with a 2 by 2 factorial arrangement with pen (6 pens/treatment) as the experimental unit using a mixed procedure of SAS (ver. 8, SAS Institute Inc., Cary, NC). An auto-regressive type 1 covariance matrix was employed as determined using Akaike's information criteria. Factors were starch, protein, and their interaction; differences were declared at $P<0.05$.

In trial 2, all ground, pelleted diets $(19 \% \mathrm{CP})$ were fed. Diets were based on soybean hulls, wheat middlings, or corn, which contained increasing concentrations of starch $(13,27$, and $42 \%$ starch, 42,23 , and $16 \%$ NDF, respectively; 8 pens/diet). The trial was conducted from August to November. The average temperature during the trial was $14^{\circ} \mathrm{C}$ (ranged from -4 to $34^{\circ} \mathrm{C}$ ) and average humidity was $72 \%$ (ranged from 30 to $99 \%$ ). The 3 treatments were analyzed as a completely randomized block design with pen as experimental unit using a mixed procedure of SAS. An auto-regressive type 1 covariance matrix was employed as determined using Akaike's information criteria. Contrast statements were constructed to separate differences in the means (soybean hulls plus wheat middlings vs. corn; soybean hulls vs. wheat middlings); differences were declared at $P<$ 0.05 .

Every second bag $(22.7 \mathrm{~kg})$ of starter feed and every bale of hay was sampled and composited. Composites of feeds were analyzed (AOAC International, 2000) for DM (oven method 930.15), ash (oven method 942.05), CP (Kjeldahl method 988.05), fat (alkaline treatment with Roese-Gottlieb method 932.06 for MR; diethyl ether extraction method 2003.05 for starters and hay), NDF with ash by the procedure of Van Soest et al. (1991) without sodium sulfite or $\alpha$-amylase, ADF with ash (Robertson and Van Soest, 1981), starch ( $\alpha$-amylase method; Hall, 2009), and sugar (colormetric method; Dubois et al., 1956). Results are in Tables 1 and 2.

Calves were weighed, hip widths were measured, and body condition was scored initially (d 28) and at the end of the trial (d 56). Empty BW was estimated from fill as a percentage of $\mathrm{BW}=10.4-0.39 \operatorname{diet} \mathrm{CP} \%$ + 0.41 diet ADF\% (Jahn and Chandler, 1976). Feed offered and refused was weighed daily. Hip widths were 
measured with a caliper. Calf BCS was based on a 1 to 5 system using 0.25 -unit increments, with 1 being emaciated and 5 being obese (Wildman et al., 1982). Scores were based on changes around the vertical and transverse processes of the spine as palpated by one experienced technician and ranged from 2.0 to 3.5. Feces were scored using a 5-point system (1 being normal, thick in consistency; 2 being normal, but less thick; 3 being abnormally thin, but not watery; 4 being watery; 5 being watery with abnormal coloring; modified from Kertz and Chester-Jones, 2004). Pen was assigned a fecal score of 0 (normal fecal score day) if no feces on the pen floor had a score greater than 2. A pen score of 1 (abnormal fecal score day) was assigned if any feces with a score greater than 2 were observed. Pen scores were analyzed.

Feeds and fecal samples during the fecal collection phase of each trial were analyzed for acid-insoluble ash
(Van Keulen and Young, 1977), an indigestible marker. The concentration of acid-insoluble ash in the feces and feed were combined with intake to estimate digestion of nutrients analyzed. Feeds and feces were analyzed for $\mathrm{DM}$, ash, CP, NDF, ADF, sugar, and starch to estimate their digestibility.

\section{RESULTS}

\section{Trial 1}

No differences $(P>0.05)$ were noted among treatments for initial BW, hip width, and BCS (Table 3). For the 56-d performance trial, calves fed the highstarch diets had greater $(P<0.05)$ ADG, empty BW ADG, feed efficiency, and change in hip width. No other differences were observed between starch levels, including no difference in days with abnormally loose feces.

Table 1. Ingredient and analyzed nutrients in feeds from trial 1

\begin{tabular}{|c|c|c|c|c|c|}
\hline \multirow[b]{2}{*}{ Item } & \multicolumn{2}{|c|}{$\begin{array}{l}\text { High-starch } \\
\text { textured feed }\end{array}$} & \multicolumn{2}{|c|}{$\begin{array}{l}\text { Low-starch } \\
\text { pelleted feed }\end{array}$} & \multirow[b]{2}{*}{ Hay } \\
\hline & Low MP & High MP & Low MP & High MP & \\
\hline \multicolumn{6}{|l|}{ Ingredient, $\%$ as fed } \\
\hline Corn $^{1}$ & 49.5 & 49.5 & 11.0 & 11.0 & - \\
\hline Oats $^{1}$ & 20.0 & 20.0 & - & - & - \\
\hline Soybean meal & 15.8 & 14.5 & 2.1 & 0.9 & - \\
\hline Wheat middlings & 8.2 & 8.9 & 33.0 & 33.0 & - \\
\hline Molasses & 3.0 & 3.0 & 3.0 & 3.0 & - \\
\hline Calcium carbonate & 0.9 & 0.9 & 0.8 & 0.8 & - \\
\hline Vitamin, trace mineral premix ${ }^{2}$ & 0.8 & 0.8 & 0.8 & 0.8 & - \\
\hline Salt & 0.8 & 0.8 & 0.8 & 0.8 & - \\
\hline Monocalcium phosphate & 0.7 & 0.7 & 0.1 & 0.1 & - \\
\hline Decoquinate premix ${ }^{3}$ & 0.5 & 0.5 & 0.5 & 0.5 & - \\
\hline Distillers dried grains & - & - & 15.0 & 15.0 & - \\
\hline Soybean hulls & - & - & 31.5 & 32.0 & - \\
\hline Blood meal & - & 0.5 & - & 0.5 & - \\
\hline Alimet $^{4}$ & - & 0.1 & - & 0.1 & - \\
\hline Sodium sesquicarbonate & - & - & 1.6 & 1.6 & - \\
\hline \multicolumn{6}{|l|}{ Nutrient } \\
\hline DM, \% & 88.4 & 89 & 89 & 88.9 & 89.3 \\
\hline Ash, $\%$ of DM & 5.5 & 5.9 & 8.1 & 7.7 & 10.2 \\
\hline $\mathrm{ADF}, \%$ of $\mathrm{DM}$ & 4.4 & 5.3 & 19.8 & 22.3 & 40.9 \\
\hline $\mathrm{NDF}, \%$ of DM & 12.6 & 13.6 & 35.6 & 35 & 65.1 \\
\hline Starch, \% of DM & 54.4 & 51.2 & 19.7 & 19.2 & 1.6 \\
\hline $\mathrm{CP}, \%$ of $\mathrm{DM}$ & 18.6 & 19.3 & 17.9 & 17.5 & 11.3 \\
\hline Sugar, \% of DM & 6.6 & 7.7 & 7.3 & 5.2 & 7.9 \\
\hline Fat, $\%$ of DM & 3.7 & 3.4 & 4.7 & 4.3 & 2.6 \\
\hline $\mathrm{DE},{ }^{5} \mathrm{Mcal} / \mathrm{kg}$ & 3.58 & 3.54 & 3.18 & 3.17 & 2.52 \\
\hline Particle size ${ }^{6} \mu \mathrm{m}$ & 3,176 & 3,192 & 934 & 920 & - \\
\hline
\end{tabular}

${ }^{1}$ Corn and oats were whole in the textured feeds and corn was ground in the pelleted feeds.

${ }^{2} 1.60 \mathrm{~g}$ of $\mathrm{Cu} / \mathrm{kg}, 0.13 \mathrm{~g}$ of $\mathrm{Co} / \mathrm{kg}, 9.40 \mathrm{~g}$ of Fe $/ \mathrm{kg}, 0.14 \mathrm{~g}$ of I $/ \mathrm{kg}, 5.4 \mathrm{~g}$ of Mn $/ \mathrm{kg}, 0.04 \mathrm{~g}$ of Se $/ \mathrm{kg}, 6.70 \mathrm{~g}$ of $\mathrm{Zn} /$ $\mathrm{kg}, 1,800 \mathrm{kIU}$ of vitamin A/kg, $600 \mathrm{kIU}$ of vitamin D/kg, $16 \mathrm{kIU}$ of vitamin E/ $\mathrm{kg}, 0.01 \mathrm{~g}$ of biotin/ $\mathrm{kg}, 2.93 \mathrm{~g}$ of obalamin $/ \mathrm{kg}, 0.04 \mathrm{~g}$ of folic acid $/ \mathrm{kg}, 1.77 \mathrm{~g}$ of niacin $/ \mathrm{kg}, 1.32 \mathrm{~g}$ of pantothenic acid $/ \mathrm{kg}, 0.24 \mathrm{~g}$ of pyridoxine/ $\mathrm{kg}, 0.30 \mathrm{~g}$ of riboflavin $/ \mathrm{kg}, 0.29 \mathrm{~g}$ of thiamin $/ \mathrm{kg}$; Provimi, Brookville, $\mathrm{OH}$.

${ }^{3} 0.5 \%$ decoquinate, Zoetis, Florham Park, NJ.

${ }^{4} 88 \%$ methionine activity, Novus International Inc., St. Charles, MO.

${ }^{5} \mathrm{DE}=$ digestible energy; calculated for analyzed nutrients using NRC (2001).

${ }^{6}$ Geometric mean particle size (ASAE, 1983) from wet sieving the complete diet (95\% concentrate, $5 \%$ chopped hay) using a vibratory sieve shaker (Fritsch, Oberstein, Germany). 
Table 2. Ingredient and analyzed nutrients in feeds from trial 2

\begin{tabular}{|c|c|c|c|c|}
\hline Item & Soyhulls & Middlings & Corn & Hay \\
\hline \multicolumn{5}{|l|}{ Ingredient, $\%$ as fed } \\
\hline Soybean hulls & 49.1 & 8.8 & 4.8 & \\
\hline Wheat middlings & 20.0 & 60.0 & 20.0 & \\
\hline Soybean meal & 19.3 & 15.1 & 23.3 & \\
\hline Maltodextrin (binder) & 2.5 & 2.5 & 2.5 & \\
\hline Molasses & 2.5 & 2.5 & 2.5 & \\
\hline Fat & 2.0 & 2.0 & 2.0 & \\
\hline Salt & 0.6 & 0.6 & 0.6 & \\
\hline Corn, ground & 1.5 & 5.7 & 41.2 & \\
\hline Monocalcium phosphate & 0.5 & 0.0 & 0.4 & \\
\hline Ameribond $2 \mathrm{X}$ (binder) ${ }^{1}$ & 0.5 & 0.5 & 0.5 & \\
\hline Decoquinate premix $^{2}$ & 0.5 & 0.5 & 0.5 & \\
\hline Vitamin, trace premix ${ }^{3}$ & 0.8 & 0.8 & 0.8 & \\
\hline Calcium carbonate & 0.3 & 1.1 & 0.9 & \\
\hline \multicolumn{5}{|l|}{ Nutrient } \\
\hline DM, \% & 88.9 & 88.4 & 88.2 & 89.4 \\
\hline Ash, $\%$ of DM & 6.7 & 7.1 & 6.4 & 10.3 \\
\hline $\mathrm{ADF}, \%$ of $\mathrm{DM}$ & 27.6 & 12.2 & 6.1 & 40.2 \\
\hline $\mathrm{NDF}, \%$ of DM & 42.9 & 23.7 & 16.4 & 63.6 \\
\hline Starch, \% of DM & 12.8 & 27 & 42.2 & 1.4 \\
\hline $\mathrm{CP}, \%$ of DM & 19 & 19.4 & 20.3 & 11.2 \\
\hline Sugar, $\%$ of DM & 7.3 & 8.7 & 8.7 & 7.8 \\
\hline Fat, $\%$ of DM & 3.6 & 5.1 & 4.7 & 2.1 \\
\hline $\mathrm{DE},{ }^{4} \mathrm{Mcal} / \mathrm{kg}$ & 3.10 & 3.42 & 3.56 & 2.52 \\
\hline Particle size ${ }^{5} \mu \mathrm{m}$ & 3,176 & 3,192 & 934 & 920 \\
\hline
\end{tabular}

${ }^{1}$ LignoTech USA Inc., Rothschild, WI.

${ }^{2} 0.5 \%$ decoquinate, Zoetis, Florham Park, NJ.

${ }^{3} 1.60 \mathrm{~g}$ of $\mathrm{Cu} / \mathrm{kg}, 0.13 \mathrm{~g}$ of $\mathrm{Co} / \mathrm{kg}, 9.40 \mathrm{~g}$ of Fe $/ \mathrm{kg}, 0.14 \mathrm{~g}$ of I $/ \mathrm{kg}, 5.4 \mathrm{~g}$ of Mn $/ \mathrm{kg}, 0.04 \mathrm{~g}$ of Se $/ \mathrm{kg}, 6.70 \mathrm{~g}$ of Zn/ $\mathrm{kg}, 1,800 \mathrm{kIU}$ of vitamin A/ kg, $600 \mathrm{kIU}$ of vitamin D/kg, $16 \mathrm{kIU}$ of vitamin $\mathrm{E} / \mathrm{kg}, 0.01 \mathrm{~g}$ of biotin $/ \mathrm{kg}, 2.93 \mathrm{~g}$ of cobalamin $/ \mathrm{kg}, 0.04 \mathrm{~g}$ of folic acid $/ \mathrm{kg}, 1.77 \mathrm{~g}$ of niacin $/ \mathrm{kg}, 1.32 \mathrm{~g}$ of pantothenic acid $/ \mathrm{kg}, 0.24 \mathrm{~g}$ of pyridoxine/ $\mathrm{kg}, 0.30 \mathrm{~g}$ of riboflavin $/ \mathrm{kg}, 0.29 \mathrm{~g}$ of thiamin $/ \mathrm{kg}$; Provimi, Brookville, $\mathrm{OH}$.

${ }^{4} \mathrm{DE}=$ digestible energy; calculated for analyzed nutrients using NRC (2001).

${ }^{5}$ Geometric mean particle size (ASAE, 1983) from wet sieving the complete diet (95\% concentrate, $5 \%$ chopped hay) using a vibratory sieve shaker (Fritsch, Oberstein, Germany).

Table 3. Performance of calves fed low- and high-starch grower diets with different amounts of MP in trial 1

\begin{tabular}{|c|c|c|c|c|c|c|c|c|}
\hline \multirow[b]{2}{*}{ Item } & \multicolumn{2}{|c|}{$\begin{array}{l}\text { High-starch } \\
\text { textured feed }\end{array}$} & \multicolumn{2}{|c|}{$\begin{array}{l}\text { Low-starch } \\
\text { pelleted feed }\end{array}$} & \multirow[b]{2}{*}{ SEM } & \multicolumn{3}{|c|}{ Main effect $P$-value } \\
\hline & Low MP & High MP & Low MP & High MP & & Starch & $\mathrm{MP}$ & Starch $\times \mathrm{MP}$ \\
\hline Initial BW, $\mathrm{kg}$ & 72.5 & 72.7 & 76.1 & 73.8 & 1.6 & 0.18 & 0.54 & 0.45 \\
\hline Final BW, kg & 132.6 & 133.9 & 132.2 & 129.8 & 2.64 & 0.41 & 0.48 & 0.83 \\
\hline ADG, kg/d & 1.07 & 1.09 & 1 & 1 & 0.032 & 0.02 & 0.79 & 0.72 \\
\hline DMI, \% BW & 3.03 & 3.08 & 3.17 & 3.23 & 0.0939 & 0.13 & 0.55 & 0.98 \\
\hline Feed efficiency, gain/feed & 0.347 & 0.344 & 0.304 & 0.304 & 0.0096 & 0.001 & 0.89 & 0.87 \\
\hline Initial hip width, cm & 21.3 & 21.5 & 21.7 & 21.5 & 0.23 & 0.47 & 0.89 & 0.31 \\
\hline Hip width change, $\mathrm{cm}$ & 6 & 5.9 & 5.4 & 5.2 & 0.22 & 0.01 & 0.62 & 0.65 \\
\hline Initial $\mathrm{BCS}^{2}$ & 2.4 & 2.3 & 2.3 & 2.3 & 0.04 & 0.55 & 0.39 & 0.73 \\
\hline BCS change & 0.6 & 0.6 & 0.6 & 0.5 & 0.051 & 0.21 & 0.54 & 0.59 \\
\hline Abnormal fecal score days ${ }^{3}$ & 4.3 & 4.3 & 4.7 & 4.8 & 0.34 & 0.22 & 0.81 & 0.82 \\
\hline
\end{tabular}

${ }^{1}$ Estimated from fill as a percentage of $\mathrm{BW}=10.4-0.39 \operatorname{diet} \mathrm{CP} \%+0.41$ diet ADF \% (Jahn and Chandler, 1976).

${ }^{2} 1$ to 5 point system $(1=$ thin, $5=$ obese) modified from Wildman et al. (1982).

${ }^{3}$ Days with any feces in pens with fecal scores $>2$; 1 to 5 system ( 1 being normal, thick in consistency; 2 being normal, but less thick; 3 being abnormally thin, but not watery; 4 being watery; 5 being watery with abnormal coloring). 
Metabolizable protein or the interactions of starch level with MP were not significant $(P>0.05)$ for any measurements.

In the digestion measurement portion of the trial, starch, ADF, NDF, and fat intakes differed $(P<0.05)$ by starch level of the diet (Table 4$)$. Fat and ADF intake differed $(P<0.05)$ by MP source. These nutrient intake differences were indicative of the nutrient concentration differences in the diet, as DMI was not different among treatments. Digestibility of DM, OM, and $\mathrm{CP}$ were greater $(P<0.05)$ for calves fed high- versus low-starch diets. Digestibility of ADF, NDF, and starch were less $(P<0.05)$ for calves fed the high- versus low-starch diets. Digestibility was not different by MP source. Amounts of ADF, NDF, and fat digested were less $(P<0.05)$ for calves fed the high- versus low-starch diets. Amount of starch digested was greater $(P<0.05)$ for calves fed the high- versus low-starch diets. Amount of ADF digested was greater $(P<0.05)$ for calves fed high- versus low-MP diets. Amount of starch and fat digested was less $(P<0.05)$ for calves fed high- versus low-MP diets.

Fecal output of DM, OM, ADF, NDF, and CP were less $(P<0.05)$ for calves fed high- versus low-starch diets. Fecal output of starch was greater $(P<0.05)$ for calves fed high- versus low-starch diets. Fecal concentrations of ADF and NDF were less $(P<0.05)$ for calves fed high- versus low-starch diets. Fecal concentrations of starch and fat were greater $(P<0.05)$ for calves fed high- versus low-starch diets. Fecal concentrations of ash were less $(P<0.05)$ in calves fed high- versus low-MP diets.

The factor of MP had limited effects on digestion. The differences in amounts of ADF, starch, and fat digested between high- versus low-MP diets appeared mostly a function of diet concentration.

Fecal output of DM and OM was 38\% greater for calves fed the high- versus low-starch diets (Table 5). Starch concentration in the manure was considerably greater (15 vs. $1 \%$ of $\mathrm{DM}$ ) in calves fed high- versus low-starch diets, whereas NDF concentration of the manure was a similar magnitude less (40 vs. $57 \%$ of DM) in calves fed high- versus low-starch diets. High fecal starch in calves fed the high-starch diets could have been inflated by the use of whole corn and oats versus ground grains. Fecal starch output in the calves fed high-starch diets was $70 \mathrm{~g}$ compared with an intake of $1,442 \mathrm{~g}$.

Table 4. Intake and digestion of nutrients by calves fed low- and high-starch grower diets with different amounts of MP during the last 2 wk of trial 1 when digestion measurements were made

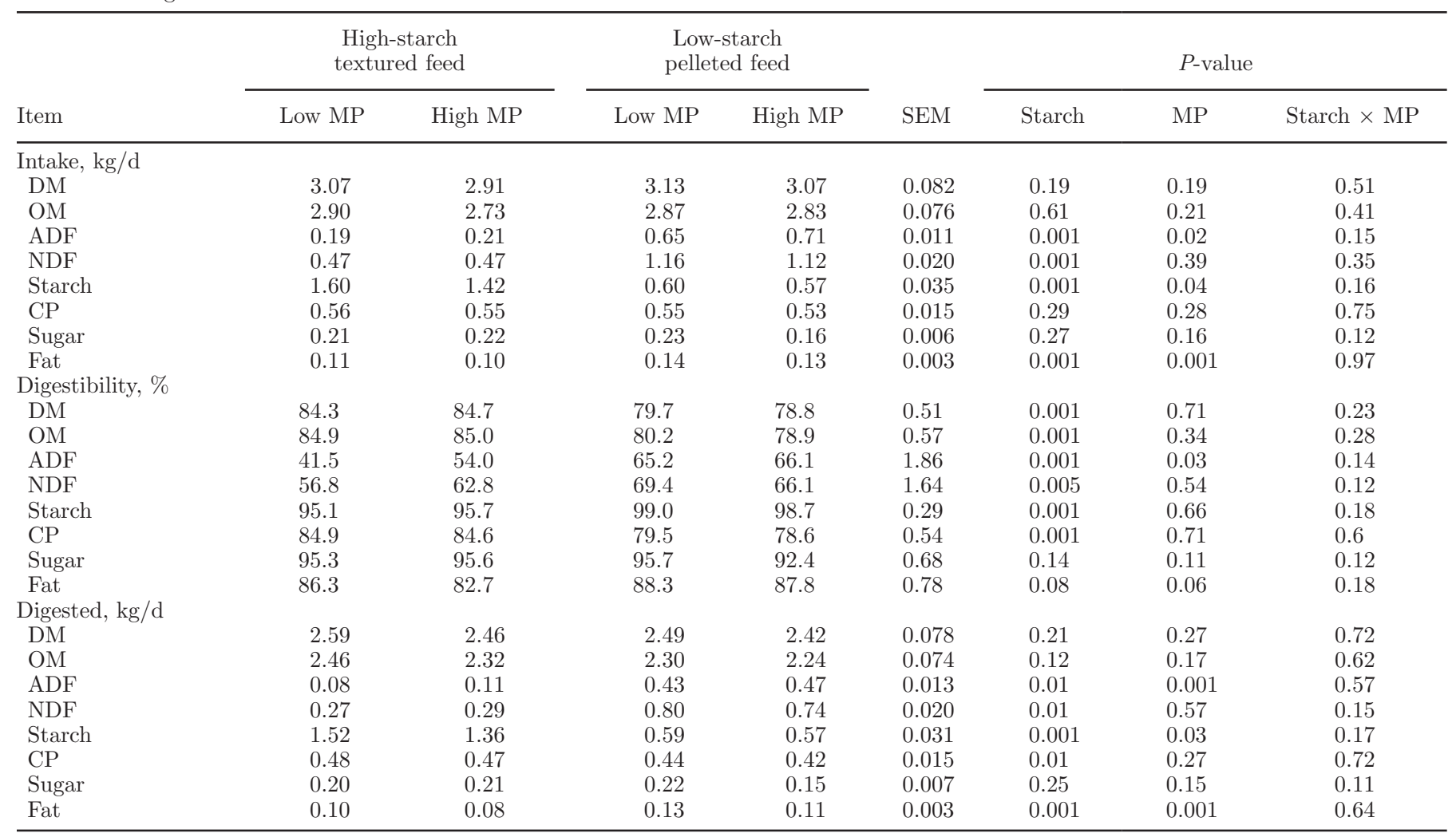


Table 5. Output of nutrients in the feces of calves fed low- and high-starch grower diets with different amounts of MP during the last 2 wk of trial 1 when digestion measurements were made

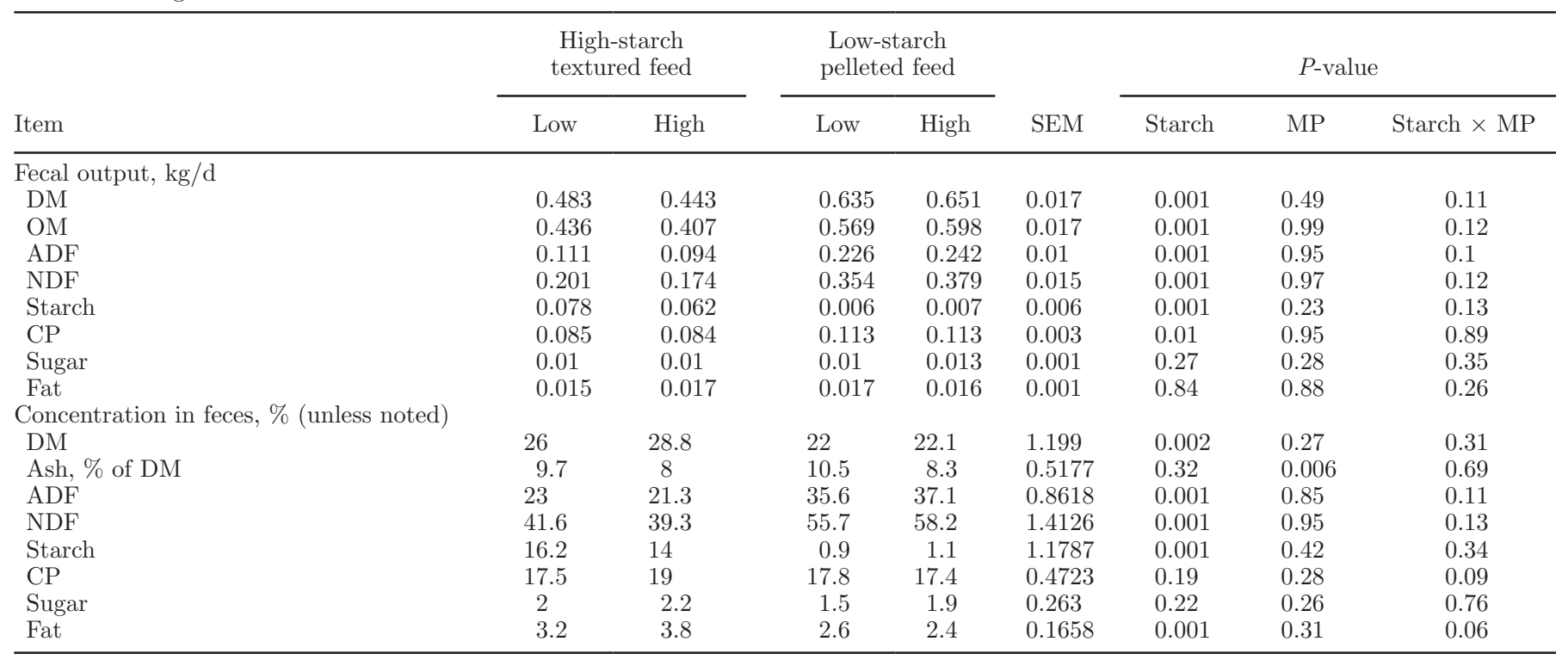

\section{Trial 2}

Initial BW, hip width, and BCS of calves in trial 2 were not different (Table $6 ; P>0.05$ ). Calf ADG, hip width change, and BCS change was greater $(P<0.05)$ for calves fed diets with corn versus soyhulls and middlings over the 56-d performance trial. Other measurements were not different $(P>0.05)$.

During the digestion measurement portion of trial 2 , starch intake ranked corn $>$ middlings $>$ soyhulls, whereas $\mathrm{ADF}$ and NDF ranked soyhulls $>$ middlings $>$ corn $(P<0.05$; Table 7$)$. These nutrient intakes reflected diet composition. Intake of DM and OM did not differ among treatments. Digestibility of DM, OM, and $\mathrm{CP}$ were greater $(P<0.05)$ for calves fed corn versus other diets. Digestibility fractions of ADF and NDF were greater $(P<0.05)$ for calves fed soyhulls versus middlings. Amount of starch digested ranked corn $>$ middlings $>$ soyhulls, whereas amount of ADF and NDF digested ranked soyhulls $>$ middlings $>$ corn $(P<0.05)$.

Fecal output of DM, OM, ADF, NDF, and CP were less $(P<0.05)$ for calves fed corn versus other diets (Table 8$)$. Fecal output of starch was greater $(P<0.05)$

Table 6. Performance of calves fed diets with different amounts of starch in trial 2

\begin{tabular}{|c|c|c|c|c|c|c|}
\hline \multirow[b]{2}{*}{ Item } & \multirow[b]{2}{*}{ Soyhulls (S) } & \multirow[b]{2}{*}{ Middlings (M) } & \multirow[b]{2}{*}{ Corn $(\mathrm{C})$} & \multirow[b]{2}{*}{ SEM } & \multicolumn{2}{|c|}{$P$-value } \\
\hline & & & & & $\mathrm{S}+\mathrm{M}$ vs. $\mathrm{C}$ & $\mathrm{S}$ vs. $\mathrm{M}$ \\
\hline Starch, $\%$ of DM & 12.8 & 27 & 42.2 & & & \\
\hline Pens, no. (4 calves/pen) & 8 & 8 & 8 & - & - & - \\
\hline Initial BW, $\mathrm{kg}$ & 70.3 & 70.3 & 72.7 & 1.5 & 0.07 & 0.94 \\
\hline Final BW, kg & 123.5 & 122.4 & 135.0 & 3.7 & 0.001 & 0.78 \\
\hline $\mathrm{ADG}, \mathrm{kg} / \mathrm{d}$ & 0.95 & 0.93 & 1.11 & 0.05 & 0.01 & 0.74 \\
\hline Empty BW ADG ${ }^{1} \mathrm{~kg} / \mathrm{d}$ & 0.68 & 0.80 & 1.02 & 0.05 & 0.01 & 0.08 \\
\hline $\mathrm{DMI}, \mathrm{kg} / \mathrm{d}$ & 3.23 & 2.90 & 3.18 & 0.19 & 0.49 & 0.11 \\
\hline DMI, $\%$ of BW & 3.33 & 3.03 & 3.07 & 0.23 & 0.61 & 0.21 \\
\hline Feed efficiency, gain/feed & 0.301 & 0.332 & 0.355 & 0.0292 & 0.14 & 0.29 \\
\hline Initial hip width, cm & 21.4 & 21.4 & 21.6 & 0.2 & 0.36 & 0.95 \\
\hline Hip width change, $\mathrm{cm}$ & 5.1 & 5.0 & 5.6 & 0.2 & 0.01 & 0.76 \\
\hline Initial $\mathrm{BCS}^{2}$ & 2.3 & 2.3 & 2.3 & 0.0 & 0.96 & 0.96 \\
\hline BCS change & 0.3 & 0.2 & 0.4 & 0.085 & 0.02 & 0.49 \\
\hline Abnormal fecal score days ${ }^{3}$ & 5.7 & 5.2 & 5.4 & 0.98 & 0.56 & 0.48 \\
\hline
\end{tabular}

${ }^{1}$ Estimated from fill as a percentage of $\mathrm{BW}=10.4-0.39 \operatorname{diet} \mathrm{CP} \%+0.41$ diet ADF \% (Jahn et al., 1976).

${ }^{2} 1$ to 5 point system $(1=$ thin, $5=$ obese) modified from Wildman et al. (1982).

${ }^{3}$ Days with any feces in pens with fecal scores $>2 ; 1$ to 5 system ( 1 being normal, thick in consistency; 2 being normal, but less thick; 3 being abnormally thin but not watery; 4 being watery; 5 being watery with abnormal coloring). 
Table 7. Intake and digestion of nutrients by calves fed diets with different amounts of starch during wk 6 and 7 of trial 2 when digestion measurements were made

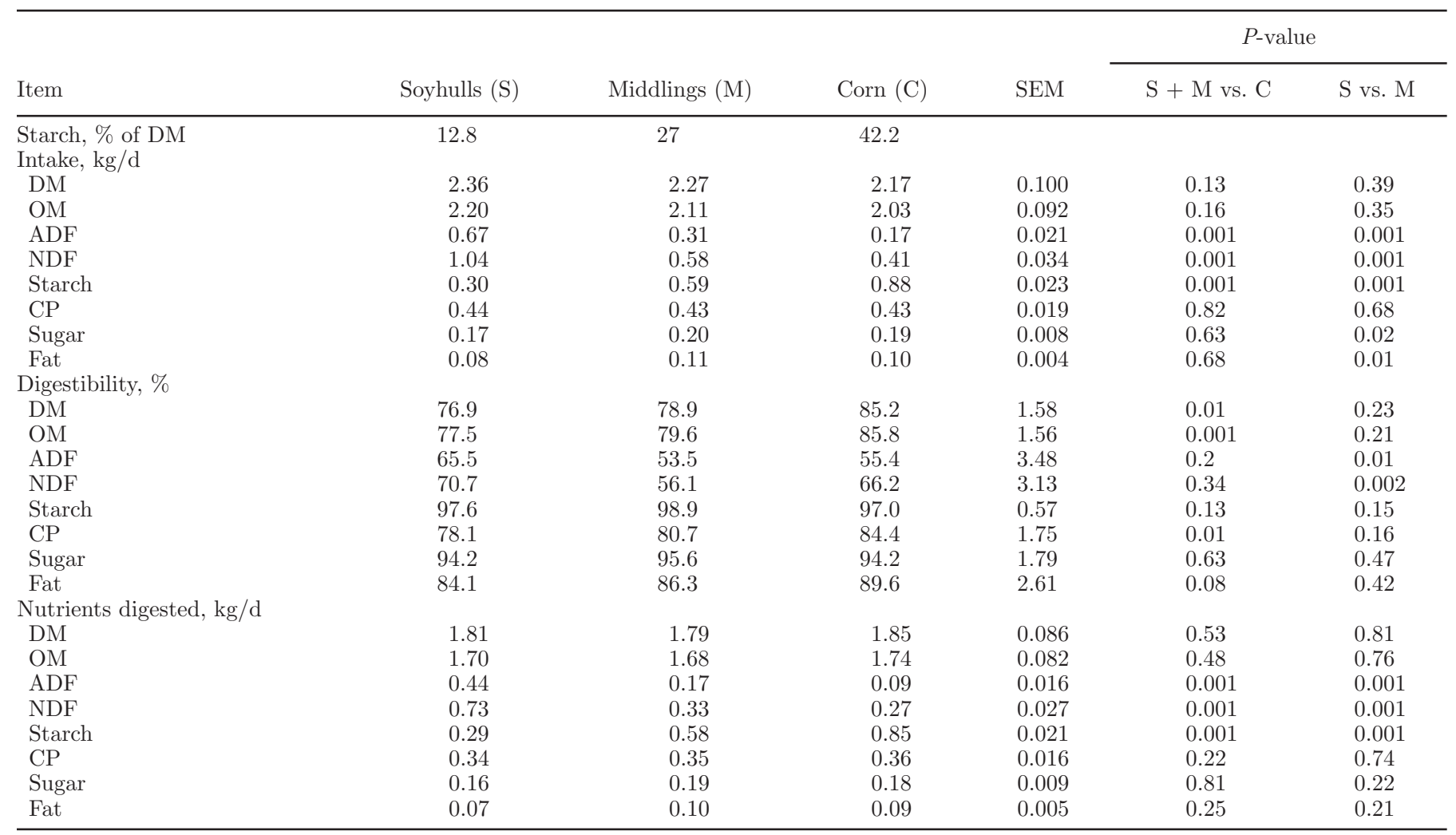

for calves fed corn versus other diets. Fecal output of and NDF were less $(P<0.05)$ for calves fed corn versus $\mathrm{ADF}$ and NDF was greater $(P<0.05)$ for calves fed other diets (Table 7$)$. Fecal concentrations of starch, soyhulls versus middlings. Fecal concentrations of ADF sugar, and CP were greater $(P<0.05)$ for calves fed

Table 8. Output of nutrients in the feces of calves fed diets with different amounts of starch during wk 6 and 7 of trial 2 when digestion measurements were made

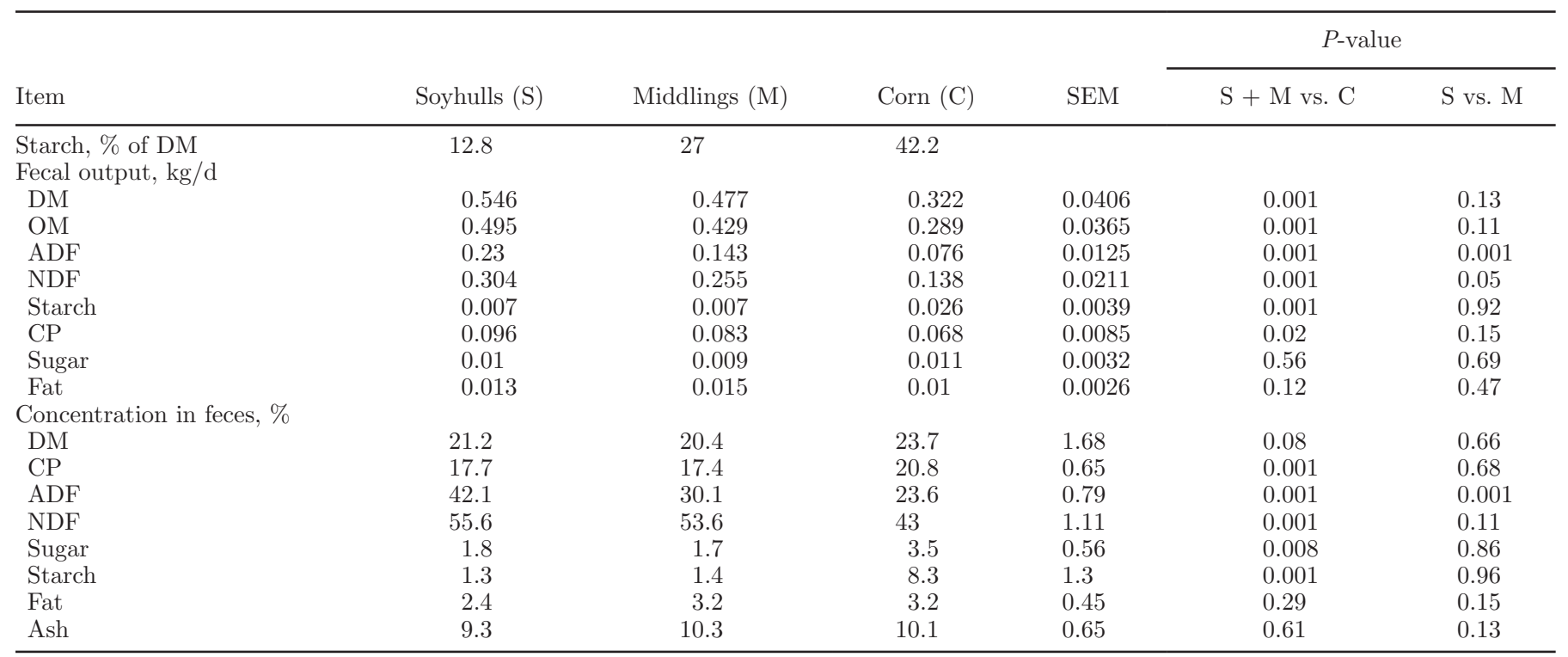


corn versus other diets. Fecal concentrations of ADF were greater $(P<0.05)$ in calves fed soyhulls versus middlings.

\section{DISCUSSION}

In trial 1, high-starch diets resulted in 2.5 times more starch being digested than in low-starch diets. Low-starch (high-fiber) diets resulted in 3.7 times more NDF being digested daily than high-starch diets. Digestibility of NDF was $67 \%$ for low-starch (high-fiber) diets compared with $59 \%$ for high-starch diets. Comparatively greater than NDF, starch digestibility was 95\% for high-starch diets and 99\% for low-starch diets. Digestibility of OM was $85 \%$ for high-starch diets, $7 \%$ greater than the $79 \%$ digestibility of OM for low-starch diets. Calculated DE was $3.56 \mathrm{Mcal} / \mathrm{kg}$ for the highstarch diet, $11 \%$ greater than the calculated DE of 3.18 $\mathrm{Mcal} / \mathrm{kg}$ for the low-starch diet.

In trial 2, starch digestibility was high $(\sim 98 \%)$ and not different among treatments, whereas NDF digestibility was lower (56 to $70 \%$ ), with middlings diets (0.56) having lower digestibility than soyhulls diets (70\%). Digestibility of OM was $8 \%$ greater for calves fed corn (85\%) versus middlings (79\%) and soyhulls $(77 \%)$. Calculated DE of the diets were $3.56,3.42$, and $3.10 \mathrm{Mcal} / \mathrm{kg}$ for corn, middlings, and soyhull diets, respectively. The energy values in NRC (2001) relate well with the digestion and performance measurements in trials 1 and 2. Current results also relate well with results of trials where distillers dried grains (low starch, high NDF) replaced corn and soybean meal (high starch, low NDF). Suarez-Mena et al. (2011) reported the digestibility of starters high in distillers dried grains to be lower and support less ADG than diets high in corn and soybean meal.

Additionally, an issue in trial 1 was confounding of starch concentration with form of diet (all pelleted, low starch with textured, and high starch). The similar results for digestion and calf performance among treatments between trial 1 and 2 suggest that the effects in trial 1 were largely related to starch concentration.

Stobo et al. (1966) fed calves weaned at 5 wk of age 90 and $33 \%$ concentrate diets. Digestibility of crude fiber was 18.4 and $57.3 \%$ at 13 wk for calves fed 90 and $33 \%$ concentrate, respectively, and 14.5 and $54.0 \%$ digestible at $17 \mathrm{wk}$, respectively. Vazquez-Anon et al. (1993) reported mean retention of particles in the rumen of calves to increase from $22 \mathrm{~h}$ at $7 \mathrm{wk}$ of age to 44 $\mathrm{h}$ at $13 \mathrm{wk}$ of age in calves fed $15 \%$ chopped grass hay and $85 \%$ concentrate diets and weaned at 5 wk of age. This would indicate that slowly digested ingredients, such as ingredients with high NDF concentrations, would yield more DE as the young calf ages.

In trial 1, fecal output of DM and OM in calves fed the low-starch diets was $38 \%$ greater than fecal output of the high-starch diets. In trial 2, fecal output of DM and $\mathrm{OM}$ was 48 and $70 \%$ greater for calves middlings and soyhulls versus corn diets, respectively. In both trials, intake of DM and OM were not different; yet, in both trials, fecal concentrations of starch were greater in calves fed high- versus lower-starch diets. This was especially true in trial 1 , where the high-starch diets were whole grains.

The difference in calf ADG was $8 \%$ greater for highversus low-starch diets in trial 1 . However, the difference in empty BW ADG was $26 \%$ more for calves fed the high- versus low-starch diet. Similarly, in trial 2, the difference in ADG from the high-starch corn diet and the average of the low-starch diets based on soyhulls or wheat middlings was considerably less than difference in empty BW ADG. This reflects the effect that fiber can have on increasing digesta fill of the gut as well as a greater amount of gut tissue (Jahn and Chandler, 1976; Fokkink et al., 2009). In research and in practical farm situations, calves are typically weighed to calculate ADG, and differences in empty BW ADG are often not measured and overlooked.

Source of protein and amount of metabolizable Lys, Met, or protein did not change performance in pre- and postweaned calves (Hill et al., 2007a, 2008b). These references contained a fairly thorough review of the literature and reported that, in trials using corn and soybean as the base ingredients, performance or digestion in calves was not improved when alternative ingredients were used; this supported no response to increasing MP in trial 1.

Lalles and Poncet (1990) and Vazquez-Anon et al. (1993) each reported that rumen degradation of protein sources increase with age postweaning. These were large changes in degradation and indicate that sources of rumen undegraded proteins are less needed in young calves than older animals with more developed rumens. In addition to no changes in growth measures, Swartz et al. (1991) reported no difference in the carcass composition from feeding diets with varying concentration of undegraded protein out to 25 wk of age.

The diets in trial 1 were formulated near the optimum $\mathrm{CP}$ concentration, as reported by Hill et al. (2008b). If energy was the limiting nutrient, not $\mathrm{CP}$ or MP, this could explain the lack of response to added MP. However, no response to added MP was noted in the lowstarch diet, where energy supply was less; this pointed to a conclusion that added MP was not beneficial. 


\section{CONCLUSIONS}

High-NDF, low-starch diets high in digestible fiber sources in $95 \%$ concentrate diets were poorly digested in dairy calves from 8 to $16 \mathrm{wk}$ of age that had been weaned at 6 wk of age compared with whole or ground high-grain, high-starch 95\% concentrate diets. This lower digestibility largely explained the lower ADG and changes in hip widths observed and supports the limited data from which the NRC (2001) requirements are based. It supports the notion that energy, not protein, limits ADG, as in NRC (2001), but does not support the notion that digestible fiber sources are useful. Increasing the metabolizable Lys and Met concentration of high- and low-starch diets based on soybean meal protein did not change digestibility or performance in these calves less than 16 wk of age. These data are similar to other recent performance reports in weaned calves of similar ages and recent performance and digestibility reports pre- and early postweaned calves less than 2 mo of age.

\section{REFERENCES}

AOAC International. 2000. Official Methods of Analysis. Vol. 1, 17th ed. AOAC International, Arlington, VA.

ASAE. 1983. Method of determining and expressing fineness of feed materials by sieving. Page 325 in ASAE Standard S319, Agriculture Engineers Yearbook of Standards. ASAE, St. Joseph, MO.

Dubois, M., K. A. Gilles, J. K. Hamilton, P. A. Rebers, and F. Smith. 1956. Colorimetric method for determination of sugars and related substances. Anal. Chem. 28:350.

FASS. 2010. Guide for the Care and Use of Agricultural Animals in Research and Teaching. 3rd ed. Federation of Animal Science Societies, Savoy, IL.

Fokkink, W. B., T. M. Hill, H. G. Bateman II, J. M. Aldrich, and R. L. Schlotterbeck. 2009. Selenium yeast for dairy calf feeds. Anim. Feed Sci. Technol. 153:228-235.

Hall, M. B. 2009. Analysis of starch, including maltooligosaccharides, in animal feeds: A comparison of methods and a method recommended for AOAC collaborative study. J. AOAC Int. 92:42-49.

Hill, T. M., J. M. Aldrich, R. L. Schlotterbeck, and H. G. Bateman II. 2007a. Protein concentration for starters fed to transported neonatal calves. Prof. Anim. Sci. 23:123-134.

Hill, T. M., H. G. Bateman II, J. M. Aldrich, and R. L. Schlotterbeck. 2008b. Crude protein for diets fed to weaned dairy calves. Prof. Anim. Sci. 24:596-603.

Hill, T. M., H. G. Bateman II, J. M. Aldrich, and R. L. Schlotterbeck. 2012. High-starch, coarse-grain, low-fiber diets maximize growth of weaned dairy calves less than 4 months of age. Prof. Anim. Sci. 28:325-331.
Hill, T. M., H. G. Bateman, J. M. Aldrich, and R. L. Schlotterbeck 2008a. Effects of feeding different carbohydrate sources and amounts to young calves. J. Dairy Sci. 91:3128-3137.

Hill, T. M., H. G. Bateman II, J. D. Quigley III, J. M. Aldrich, R. L. Schlotterbeck, and A. J. Heinrichs. 2013. Review: New information on the protein requirements and diet formulation for dairy calves and heifers since the Dairy NRC 2001. Prof. Anim. Sci. 29:199-207.

Jahn, E., and P. T. Chandler. 1976. Performance and nutrient requirements of calves fed varying percentages of protein and fiber. J. Anim. Sci. 41:724-735.

Kertz, A. F., and H. Chester-Jones. 2004. Invited review: Guidelines for measuring and reporting calf and heifer experimental data. J. Dairy Sci. 87:3577-3580.

Lalles, J. P., and C. Poncet. 1990. Changes in ruminal and intestinal digestion during and after weaning in dairy calves fed concentrate diets containing pea or soya bean meal. 1. Digestion of organic matter and nitrogen. Livest. Prod. Sci. 24:129-142.

NRC. 2001. Nutrient Requirements of Dairy Cattle. 7 th rev. ed. Natl. Acad. Sci., Washington, DC.

Robertson, J. B., and P. J. Van Soest. 1981. The Detergent System of Analysis and its Application to Human Foods. Cornell University, Ithaca, NY.

Stamey, J. A., N. A. Janovick, A. F. Kertz, and J. K. Drackley. 2012 Influence of starter protein content on growth of dairy calves in an enhanced early nutrition program. J. Dairy Sci. 95:3327-3336.

Stobo, I. J. F., J. H. B. Roy, and H. J. Gaston. 1966. Rumen development in the calf. Br. J. Nutr. 20:189-215.

Suarez-Mena, F. X., T. M. Hill, A. J. Heinrichs, H. G. Bateman II, J. M. Aldrich, and R. L. Schlotterbeck. 2011. Effects of including corn distillers dried grains with solubles in dairy calf feeds. J. Dairy Sci. 94:3037-3044.

Swartz, L. A., A. J. Heinrichs, G. A. Varga, and L. D. Muller. 1991. Effects of varying dietary undegradable protein on dry matter intake, growth, and carcass composition of Holstein calves. J. Dairy Sci. 74:3884-3890.

Terré, M., E. Pedrals, A. Dalmau, and A. Bach. 2013. What do preweaned and weaned calves need in the diet: A high fiber content or a forage source? J. Dairy Sci. 96:5217-5225.

Van Keulen, J. V., and B. A. Young. 1977. Evaluation of acid insoluble ash as a natural marker in ruminant digestibility studies. J. Anim. Sci. 44:282-287.

Van Soest, P. J., J. B. Robertson, and B. A. Lewis. 1991. Methods for dietary fiber, neutral detergent fiber, non-starch polysaccharides in relation to animal nutrition. Symposium: Carbohydrate methodology, metabolism and nutritional implications in dairy cattle. J. Dairy Sci. 74:3583-3597.

Vazquez-Anon, M., A. J. Heinrichs, J. M. Aldrich, and G. A. Varga. 1993. Effect of postweanlng age on rate of in situ protein disappearance in calves weaned at 5 weeks of age. J. Dairy Sci. 76:27492757.

Warner, R. G. 1984. The impact of protein solubility in dairy calf starters. Pages 42-45 in Proc. Cornell Nutr. Conf. Feed Manuf. Rochester, NY. Cornell University, Ithaca, NY.

Wildman, E. E., G. M. Jones, P. E. Wagner, R. L. Bowman, H. F. Troutt Jr., and T. N. Lesch. 1982. A dairy cow body condition scoring system and its relationship to selected production characteristics. J. Dairy Sci. 65:495-501. 